\title{
Produksi 23 Klon Singkong Di Desa Muara Putih, Kecamatan Natar,
} Kabupaten Lampung Selatan

\author{
Yield of 23 Cassava Clones In Muara Putih Village, Natar, South Lampung
}

\author{
Setyo Dwi Utomo', Anggista Mega Fiska', Ihsania Niluh Jinggan ${ }^{1}$, Akari Edy ${ }^{1}$, Kukuh Setiawan', \\ Sunyoto ${ }^{1}$ \\ ${ }^{1}$ Jurusan Agroteknologi Fakultas Pertanian Universitas Lampung, Bandar Lampung, 35141 \\ *Email: setyo.dwiutomo@fp.unila.ac.id
}

Disubmit: 14 September 2019 Direvisi: 25 Desember 2019 Diterima: 23 Januari 2020

\begin{abstract}
Abstrak: Penelitian ini bertujuan untuk menguji daya hasil 23 klon ubi kayu yang dibandingkan dengan klon standar yaitu klon UJ5. Penelitian terdiri atas 2 percobaan yaitu Percobaan A dan B. Penelitian dilakukan pada bulan Mei 2017 hingga April 2018 di Desa Muara Putih, Natar, Lampung Selatan. Uji asam sianida dilakukan di Laboratorium Teknologi Hasil Pertanian Politeknik Negeri Lampung, Bandar Lampung. Rancangan percobaan yang digunakan yaitu Rancangan Acak Kelompok (RAK) yang terdiri atas dua ulangan untuk percobaan $\mathrm{A}$, dan tiga ulangan untuk percobaan $\mathrm{B}$. Karakter kuantitatif dianalisis ragam dan diuji lanjut menggunakan uji Beda Nyata Terkecil (BNT) dan Dunnett taraf nyata 5\%. Hasil penelitian percobaan A menunjukkan Klon CMM 96-1-102, 19-Daniel, BL-1, Bayam Liwa 5, dan SL-36 memiliki jumlah ubi lebih banyak dari klon UJ5. Klon CMM 96-1-102, UJ 6, Litbang UK 2, SL-36, Korem Gatam, dan UJ6 memiliki bobot ubi segar per tanaman yang lebih tinggi dibandingkan klon UJ5. Klon Litbang UK 2, SL-106, UJ3, UJ6, dan CMM 96-1102 memiliki indeks panen yang lebih tinggi dibandingkan klon UJ5. Kadar pati tinggi yaitu klon CMM 25-27-23-10-25, CMM 96-1-102, Bayam Liwa 5, BL-1, dan SL-36. Sedangkan percobaan B menunjukkan klon UJ 5 memiliki jumlah ubi terbanyak diikuti dengan klon Nibung. Klon MU 55, Gajah, Nibung, UJ 3, dan Korem Gatam memiliki bobot ubi segar per tanaman yang lebih tinggi dari klon UJ 5. Klon UJ 5 memiliki kadar pati tertinggi dan diikuti oleh klon Nibung dan Korem Gatam.
\end{abstract}

Kata kunci: Keragaman, klon unggul, Manihot esculenta, uji daya hasil.

Abstract: This research was aimed to examine the yield of 23 cassava clones compare to the check clone which is UJ5 clone. This research consisted of 2 experiments which are Experiments $A$ and B. This research was conducted in May 2017 to April 2018 in Muara Putih Village, Natar, South Lampung. Cyanide acid test was carried out at the Lampung State Polytechnic Agricultural Product Technology Laboratory, Bandar Lampung. The design used a randomized complete block design with two replications for experiment $A$, and three replications for experiment $B$. Quantitative characters were analyzed and tested by using the Least Significant Difference (LSD) test and Dunnett's 5\% significance level. The results of experiment $A$ showed that CMM clones 96-1-102, 19-Daniel, BL-1, Spinach Liwa 5, and SL36 have more root than UJ5. CMM clones 96-1-102, UJ 6, UK R\&D 2, SL-36, Korem Gatam, and UJ6 have bigger weight of fresh root per plant than UJ5. UK R\&D clones 2, SL-106, UJ3, UJ6, and CMM 96-1-102 have a higher harvest index than UJ5. High starch levels are CMM clones 25-27-23-10-25, CMM 96-1-102, Spinach Liwa 5, BL-1, and SL-36. Meanwhile experiment $B$ showed that UJ 5 has the bigger number of root followed by Nibung. MU 55 clones, Gajah, Nibung, UJ 3, and Korem Gatam have bigger weight of fresh root per plant than UJ 5. UJ 5 has the highest starch content followed by Nibung and Koram Gatam clones.

Keywords: Cassava clones, diversity, Manihot esculenta Crantz, yield analysis. 


\section{PENDAHULUAN}

Ubi kayu berasal dari kawasan Benua Amerika beriklim tropis. Penyebaran ubi kayu pertama kali terjadi di Afrika, Madagaskar, India dan TiongkokNikolai ivanovich Vavilow, seorang ahli botani Soviet memastikan tempat asal ubi kayu adalah negara Brazil (Amerika Selatan). Penyebaran ubi kayu pertama kali terjadi di Afrika, Madagaskar, India, Tiongkok, dan beberapa negara yang terkenal daerah pertaniannya (Rukmana, 1997). Ubi kayu memiliki manfaat dan kandungan gizi seperti karbohidrat, lemak, protein, serat makanan, vitamin (B1, C), mineral (Fe, F, $\mathrm{Ca}$ ), dan zat non gizi yaitu air. Selain itu, ubi kayu juga mengandung senyawa non gizi tanin (Soenarso dan Soehardi, 2004). Semua bagian tanaman ubi kayu dapat dimanfaatkan mulai dari daun, batang, umbi, hingga bagian kulit. Banyaknya manfaat yang dimiliki oleh ubi kayu menjadikan tanaman ini sebagai komoditi unggulan untuk memenuhi kebutuhan dalam dan luar negeri. Berdasarkan potensi Manfaat yang ada dimiliki oleh ubi kayu mendorong Indonesia untuk terus meningkatkan produksi dan produktivitas ubi kayu.

Produktivitas ubi kayu di Indonesia dapat diperoleh melalui hubungan perbandingan lurus antara luas panen dan produksi itu sendiri. Berdasarkan data yang diperoleh dari BPS, (2018), menyatakan bahwa ubi kayu mencapai nilai produksinya sebesar 21.801.415 ton dengan luas areal panen 949.916 ha pada tahun 2015. Hasil ini dengan mengalami penurunan apabila dibandingkan dengan produksi ubi kayu pada tahun 2014 yaitu sebesar 23.436.384 ton dengan luas areal panen 1.003.494 ha. Lampung merupakan provinsi penghasil ubi kayu terbesar di Indonesia dengan produksi 7.387.084 ton pada luas areal panen 279.337 ha atau setara dengan 26 ton/ha.

Produksi ubi kayu di Indonesia belum mampu memenuhi kebutuhan bahan baku pangan serta dan bahan baku industri baik di dalam maupun di dan luar negeri akibat adanya penurunan produksi ubi kayu yang disebabkan oleh luas areal panen,dan terbatasnya penggunaan varietas unggul yang berdaya hasil tinggi (Karama, 2003). Oleh karena itu diperlukan penerapan teknologi untuk mendorong peningkatan produksi ubi kayu, salah satunya adalah dengan penggunaan varietas unggul. Penggunaan varietas unggul penting dalam untuk mendapatkan produksi ubi kayu yang tinggi pada luasan panen ubi kayu di Indonesia (Saleh dan Widodo, 2007). Upaya peningkatan mutu dan produksi ubi kayu dengan tersedianya bibit varietas unggul diharapkan mampu memenuhi kebutuhan pangan dan industri serta meningkatkan pendapatan petani. Pengembangan varietas unggul dapat dilakukan melalui kegiatan pemuliaan tanaman.

Pemuliaan tanaman merupakan suatu kegiatan yang dilakukan untuk memperbaiki genetik karakter tanaman. yang diwariskan pada suatu populasi baru dengan sifat genetik baru, dalam hal ini yaitu tanaman ubi kayu. Tahap-tahap perakitan varietas ubi kayu hingga tahap pelepasan varietas meliputi perluasan keragaman genetik populasi awal, seleksi klon, dan uji daya hasil dan uji multi lokasi (CIAT, 2005). Sebelum ditetapkan menjadi sebagai varietas unggul, klon-klon hasil pemuliaan perlu dilakukan perlu adanya uji daya hasil mengenai klon baru untuk mengidentifkasi karakteristik varietas dan mengetahui keragaman klon ubi kayu. Potensi hasil yang diperoleh pada dari klon unggul baru selanjutnya akan dibandingkan dengan klon standar ubi kayu yaitu UJ 5. Apabila klon unggul baru menunjukkan menghasilkan potensi hasil yang lebih tinggi dibandingkan baik dari klon standar UJ 5, maka klon tersebut merupakan kandidat varietas unggul baru sebelum dilakukan uji selanjutnya.akan dijadikan sebagai varietas unggul baru 
dengan produksi dan produktivitas yang tinggi. Penelitian ini bertujuan untuk menguji daya hasil dari 23 klon ubi kayu.

\section{METODE PENELITIAN}

\section{Alat dan Bahan}

Penelitian ini dilaksanakan di Kebun Percobaan Universitas Lampung yang terletak di Desa Muara Putih, Kecamatan Natar, Kabupaten Lampung Selatan pada bulan Mei 2017 - April 2018. Pengujian kandungan asam sianida (HCN) dilakukan di Laboratorium Teknologi Hasil Pertanian Politeknik Negeri Lampung, Bandar Lampung.

Alat yang digunakan yaitu alat tulis, golok, cangkul, meteran, jangka sorong digital, timbangan digital, alat ukur kadar pati Thai Sang Metric co. Ltd, pisau, parut, beaker glass, sendok, alat destilasi, erlenmeyer, buret, baskom, neraca analitik, talenan, labu ukur, pipet volumetrik, pipet tetes, kamera digital, dan alat tulis. Bahan yang digunakan adalah stek batang 21 klon ubi kayu air, pupuk NPK Mutiara dengan dosis $300 \mathrm{~kg} / \mathrm{ha}$, dan herbisida berbahan aktif Paraquat, $\mathrm{AgNO}_{3} 0,002 \mathrm{~N}, \mathrm{KI} 5 \%$, aquadest, $\mathrm{NaOH} 2,5 \%$, dan $\mathrm{NH}_{4} \mathrm{OH}$.

\section{Metode Penelitian}

Pada percobaan $A$, penelitian dilakukan menggunakan rancangan acak kelompok (RAK) berdasarkan plot yang terdiri dari 3 ulangan. Setiap ulangan terdiri dari 8 baris klon sebagai perlakuan yang masing-masing klon terdiri dari 2 baris tanaman dengan satu baris tanaman terdiri dari 10 tanaman, dan terdapat 20 tanaman untuk setiap klonnya, sehingga dieproleh 48 satuan percobaan.

Pada percobaan $\mathrm{B}$, penelitian dilakukan menggunakan rancangan acak kelompok (RAK) berdasarkan plot yang terdiri dari 2 ulangan sehingga diperoleh 30 satuan percobaan.

Ubi kayu ditanam dengan jarak tanam $100 \mathrm{~cm} \times 50 \mathrm{~cm}$. Pemeliharaan dilakukan meliputi pengguludan, pemupukan dan pengendalian gulma. Penyiraman dilakukan dengan berdasarkan curah hujan. Pengguludan dilakukan setelah 1-2 BST (bulan setelah tanam). Pemupukan dilakukan dengan menggunakan pupuk NPK Mutiara 15:15:15 dengan dosis $300 \mathrm{~kg} / \mathrm{ha}$. Pemanenan dilakukan saat tanaman berumur 11 BST. Pemanenan dilakukan untuk mengetahui produksi dari masing-masing klon. Uji selanjutnya yaitu uji kadar pati, dan asam sianida ( $\mathrm{HCN})$.

\section{Variabel Pengamatan}

Variabel pengamatan terdiri dari jumlah ubi, bobot ubi segar per tanaman, kadar pati, dan kadar asam sianida ( $\mathrm{HCN})$.

Perhitungan jumlah ubi dilakukan dengan cara menghitung ubi yang terdapat pada setiap tanaman sampel. Perhitungan jumlah ubi dilakukan saat tanaman berumur 11 BST.

Penimbangan bobot ubi dilakukan pada ubi yang terdapat di setiap tanaman sampel dari masing-masing klon. Bobot ubi per tanaman dihitung dari bobot ubi yang dihasilkan dari setiap tanaman sampel pada masing-masing klon yang dibagi dengan jumlah tanaman. Penimbangan dilakukan dengan menggunakan timbangan gantung dan dinyatakan dalam satuan gram. Penimbangan bobot ubi dilakukan saat tanaman berumur 11 BST. 
Pengukuran kadar pati berdasarkan perbandingan bobot ubi di udara dan di air. Pengukuran kadar pati menggunakan alat timbangan Thai Sang Metric co. Ltd. Pengukuran kadar pati dilakukan setelah pemanenan saat tanaman berumur 11 bulan. Tiap klon diambil $5 \mathrm{~kg}$ ubi segar per sampel. Apabila bobot ubi segar tidak mencapai $5 \mathrm{~kg}$, maka tidak dilakukan pengukuran kadar pati. Kemudian ubi segar dicacah atau dipotong-potong dengan ukuran $\pm 5 \times 5 \mathrm{~cm}$, lalu ditimbang udara. Selanjutnya, ditimbang basah dan diatur keseimbangan timbangan untuk mengetahui nilai kadar pati ubi kayu.

Pengukuran kadar asam sianida ( $\mathrm{HCN}$ ) yaitu ditimbang sampel ubi kayu yang sudah dihaluskan sebanyak 5 - 10 gram, dipindahkan kedalam labu ukur dan ditambah $100 \mathrm{ml}$ aquades, kemudian didiamkan selama 2 jam. Ditambah $100 \mathrm{ml}$ aquades kemudian dilakukan distilasi, distilat ditampung pada erlenmeyer yang berisi $20 \mathrm{ml} \mathrm{NaOH}$ 2,5\%. Distilasi diakhiri

setelah distilat mencapai $150 \mathrm{ml}$, ditambahkan $8 \mathrm{ml} \mathrm{NH} 4 \mathrm{OH}$ dan $5 \mathrm{ml} \mathrm{KI} \mathrm{5 \%}$

lalu dititrasi dengan $\mathrm{AgNO} 3$ 0,02 N sampai timbul warna keruh. Catatan: $1 \mathrm{ml}$ AgNO3 0,02 $\mathrm{N}$ setara dengan 0,54 $\mathrm{mg} \mathrm{HCN}$.

Perhitungan kadar HCN menggunakan rumus sebagai berikut:

$\mathrm{HCN}=\frac{\mathrm{ml} \text { titrasi AgNO3 } \times 0,54}{\mathrm{~g} \text { sampel }} \mathrm{mg} / \mathrm{g}$

(1) (Sudarmadji, Haryono dan Suhardi, 1984)

\section{Analisis Data}

Data yang diperoleh dari percobaan $\mathrm{A}$ dan $\mathrm{B}$ dianalisis ragam dan diuji lanjut menggunakan uji Beda Nyata Terkecil (BNT) dan Dunnet taraf nyata 5\%. Analisis data tersebut menggunakan Software The SAS System Windows 9.0.

\section{HASIL DAN PEMBAHASAN}

\section{Hasil}

\section{Percobaan $A$}

Jumlah ubi terbanyak pada klon CMM 96-1-102 diikuti dengan klon 19 Daniel dan BL1, sedangkan klon pembanding UJ5 diurutan ke-5. Bobot ubi segar per tanaman tertinggi yaitu klon CMM 96-1-102 yang diikuti dengan klon Litbang UK 2 dan SL-36, sedangkan klon pembanding UJ5 diurutan ke 11 (Tabel 1).

Klon pembanding UJ5 diduga memiliki nilai kadar pati tertinggi karena pada kelompok 2 kadar patinya sebesar 33,40\%. Klon tertinggi lainnya yaitu CMM 25-1713-10-15, CMM 96-1-102, dan Bayam Liwa 5. Kadar asam sianida (HCN) tertinggi pada Klon Korem Gatam yaitu sebesar $0,5130 \mathrm{mg} / \mathrm{g}$ sedangkan klon pembanding UJ5 menunjukkan kadar HCN sebesar $0,1000 \mathrm{mg} / \mathrm{g}$ (Tabel 2). Berdasarkan deskripsi klon unggul nasional, klon UJ5 memiliki rasa pahit yang menunjukkan bahwa klon tersebut memiliki kadar $\mathrm{HCN}>0,08 \mathrm{mg} / \mathrm{g}$. 
Tabel 1. Nilai tengah jumlah ubi per tanaman, bobot ubi segar per tanaman, dan bobot ubi segar per ha

\begin{tabular}{ccccc}
\hline No & Klon & $\begin{array}{c}\text { Jumlah } \\
\text { ubi (buah) }\end{array}$ & $\begin{array}{c}\text { Bobot ubi segar } \\
\text { per tanaman } \\
\text { (g/tanaman) }\end{array}$ & $\begin{array}{c}\text { Bobot ubi segar } \\
\text { per ha (ton/ha) }\end{array}$ \\
\hline 1 & UJ5 & 6 & 1251,25 & 25,03 \\
2 & BL-1 & 7 & 1213,21 & 24,26 \\
3 & Korem Gatam & 5 & 1656,25 & 33,13 \\
4 & SL-106 & 5 & 454,29 & 9,09 \\
5 & UJ3 & 4 & 1250,00 & 25,00 \\
6 & BL 8-1 & 5 & 1367,50 & 27,35 \\
7 & SL-36 & 6 & 1682,50 & 33,65 \\
8 & UJ3 Kecil & 5 & 973,33 & 19,47 \\
9 & Pekalongan & 5 & 1587,50 & 31,75 \\
10 & Bayam Liwa 5 & 6 & 1699,44 & 33,99 \\
11 & Litbang UK 2 & 4 & 2035,00 & 40,70 \\
12 & CMM-96-1-1 102 & 9 & 1505,00 & 30,10 \\
13 & Randu & 5 & 1338,50 & 26,77 \\
14 & 19 Daniel & 8 & 1624,56 & 32,49 \\
15 & UJ6 & 5 & 1332,14 & 26,64 \\
\hline
\end{tabular}

Tabel 2. Kadar pati dan HCN ubi kayu

\begin{tabular}{|c|c|c|c|c|}
\hline No & Klon & $\begin{array}{l}\text { Kadar } \\
\text { Pati }\end{array}$ & $\mathrm{HCN}(\mathrm{mg} / \mathrm{g})$ & HCN (ppm) \\
\hline 1 & UJ5 & 33,40 & 0,1000 & 100,00 \\
\hline 2 & BL-1 & 30,28 & 0,0660 & 66,00 \\
\hline 3 & Korem Gatam & 28,65 & 0,5130 & 513,00 \\
\hline 4 & SL-106 & 27,90 & 0,0814 & 81,40 \\
\hline 5 & UJ3 & 25,55 & 0,1858 & 185,80 \\
\hline 6 & $\mathrm{BL}$ 8-1 & 24,25 & 0,0927 & 92,70 \\
\hline 7 & SL-36 & 30,05 & 0,0799 & 79,90 \\
\hline 8 & $\begin{array}{l}\text { UJ3 Kecil } \\
\text { Pekalongan }\end{array}$ & 26,00 & - & - \\
\hline 9 & Bayam Liwa 5 & 30,35 & 0,0638 & 63,80 \\
\hline 10 & Litbang UK 2 & 27,95 & 0,1068 & 106,80 \\
\hline 11 & CMM-96-1-1 102 & 31,45 & 0,3138 & 313,80 \\
\hline 12 & Randu & 24,00 & - & - \\
\hline 13 & 19 Daniel & 27,90 & 0,0414 & 41,40 \\
\hline 14 & UJ6 & 27,30 & 0,1298 & 129,80 \\
\hline 15 & $\begin{array}{l}\text { CMM 25-27-23- } \\
\quad 10-15\end{array}$ & 32,25 & 0,1261 & 126,10 \\
\hline
\end{tabular}

\section{Percobaan B}

Jumlah ubi per tanaman nyata dipengaruhi oleh klon. Jumlah ubi terbanyak pada klon UJ5 diikuti dengan klon Nibung. Berdasarkan uji BNT menunjukkan bahwa klon MU 55, UJ 3, BL 2, Gajah, Korem Gatam, dan 17 berbeda nyata dengan klon pembanding UJ 5. Sedangkan klon Nibung tidak berbeda nyata dengan klon pembanding UJ 5.

Pada variabel bobot ubi nyata dipengaruhi klon. Bobot ubi segar per tanaman tertinggi yaitu klon MU55 yang diikuti dengan klon Gajah, Nibung, sedangkan klon pembanding UJ5 diurutan ke 7. Berdasarkan uji lanjut Uji BNT menunjukkan bahwa 
klon MU 55 dan BL 2 berbeda nyata dengan klon pembanding UJ 5, sedangkan klon Gajah, Korem Gatam, Nibung, dan 17 tidak berbeda nyata dengan klon pembanding UJ 5. (Tabel 3).

Tabel 3. Nilai tengah jumlah ubi per tanaman, bobot ubi segar per tanaman, dan bobot ubi segar per ha

\begin{tabular}{ccccc}
\hline No. & Klon & $\begin{array}{r}\text { Jumlah } \\
\text { ubi (buah) }\end{array}$ & $\begin{array}{c}\text { Bobot ubi segar per } \\
\text { tanaman (g/tanaman) }\end{array}$ & $\begin{array}{c}\text { Bobot ubi } \\
\text { segar per ha } \\
\text { (ton/ha) }\end{array}$ \\
\hline 1 & MU 55 & $3 \mathrm{~b}$ & $854,34 \mathrm{a}$ & 17,08 \\
2 & UJ 3 & $3 \mathrm{~b}$ & $583,83 \mathrm{~b}$ & 11,68 \\
3 & BL 2 & $3 \mathrm{~b}$ & $143,15 \mathrm{c}$ & 2,86 \\
4 & Gajah & $3 \mathrm{~b}$ & $647,98 \mathrm{ab}$ & 12,96 \\
5 & Korem Gatam & $3 \mathrm{~b}$ & $595,00 \mathrm{ab}$ & 11,90 \\
6 & Nibung & $4 \mathrm{ab}$ & $603,03 \mathrm{ab}$ & 12,06 \\
7 & 17 & $3 \mathrm{~b}$ & $593,08 \mathrm{ab}$ & 11,86 \\
8 & UJ 5 & $6 \mathrm{a}$ & $471,10 \mathrm{~b}$ & 9,42 \\
\hline & BNT 5\% & 1,88 & 270,36 & \\
\hline
\end{tabular}

Keterangan : Angka pada kolom yang diikuti dengan huruf yang sama tidak berbeda nyata berdasarkan uji Beda Nyata Terkecil (BNT) $5 \%$.

Klon pembanding UJ5 memiliki nilai kadar pati tertinggi yaitu sebesar $30,77 \%$. Klon dengan kadar pati tertinggi lainnya yaitu Nibung dan Korem Gatam (Tabel 4). Kadar asam sianida (HCN) tertinggi pada Klon pembanding UJ 5 yaitu sebesar $0,2153 \mathrm{mg} / \mathrm{g}$ (Tabel 4). Berdasarkan deskripsi klon unggul nasional, klon UJ5 memiliki rasa pahit yang menunjukkan bahwa klon tersebut memiliki kadar $\mathrm{HCN}$ $>0,08 \mathrm{mg} / \mathrm{g}$.

Tabel 4. Kadar pati dan HCN ubi kayu

\begin{tabular}{ccccc}
\hline No & Klon & Kadar Pati & HCN $(\mathrm{mg} / \mathrm{g})$ & HCN $(\mathrm{ppm})$ \\
\hline 1 & MU 55 & 24,33 & 0,2071 & 207,11 \\
2 & UJ 3 & 25,60 & 0,1997 & 199,75 \\
3 & BL 2 & - & 0,2037 & 203,67 \\
4 & Gajah & 25,48 & 0,1184 & 118,43 \\
5 & UJ 5 & 30,77 & 0,2153 & 215,30 \\
6 & Korem Gatam & 26,43 & 0,1667 & 166,75 \\
7 & Nibung & 27,50 & 0,1626 & 162,56 \\
8 & 17 & 24,63 & 0,1604 & 160,38 \\
\hline
\end{tabular}

\section{Pembahasan}

Menurut Gomes et al. (2016) jumlah ubi dipengaruhi oleh kondisi lingkungan dan alokasi hasil fotosintat ke akar selama tahap awal perkembangan ubi kayu. Jumlah ubi yang sedikit terjadi karena meningkatnya kepadatan populasi tanaman. Hal ini didukung oleh pendapat Sumartono (2013) yang menyatakan bahwa pembentukan ubi dipengaruhi oleh kondisi lingkungan atau media tanam, kekurangan oksigen akibat aerasi tanah yang buruk dapat menghambat pembelahan dan pembesaran sel yang akan berdampak pada perkembangan ubi baru. Dalam pembentukan ubi, tanaman ubi kayu sangat memerlukan hara $\mathrm{P}$ dan $\mathrm{K}$ yang cukup. Pupuk $P$ sangat berperan dalam meningkatkan jumlah ubi, karena hara $P$ sangat diperlukan dalam pembentukan akar tanaman (Tumewu, Paruntu dan Sondakh, 
2015). Jumlah ubi dan diameter umbi merupakan komponen hasil yang berkontribusi untuk meningkatkan hasil ubi kayu (Ntawuruhunga and Dixon, 2010).

Menurut Balitkabi (2011), klon UJ5 dalam deskripsi klon unggul nasional memiliki potensi hasil sebesar 25-38 ton per ha. Pada penelitian ini, klon pembanding UJ5 memiliki rataan bobot ubi segar per tanaman 25,03 ton per ha. Proses pembesaran ubi membutuhkan unsur hara $\mathrm{K}$. Unsur hara $\mathrm{K}$ berperan penting dalam proses metabolisme. Kalium menstimulir aktivitas fotosintesis dan meningkatkan translokasi hasil fotosintesa ke bagian ubi (untuk pembesaran ubi) (Radjit, 2014).

Pada variabel kadar pati, secara kuantitas klon UJ 5 sebagai pembanding memiliki nilai tengah kadar pati tertinggi yaitu sebesar 33,40\% dan 30,77\%. Kandungan pati sangat dipengaruhi oleh umur ubi kayu. Semakin tua umur panen ubi kayu maka semakin tinggi kadar pati yang dihasilkan. Susilawati, Nurdjannah dan Putri (2008) menyatakan bahwa peningkatan kadar pati disebabkan oleh semakin banyaknya granula pati yang terbentuk di dalam ubi. Ubi kayu dengan kadar pati tinggi cukup potensial apabila digunakan sebagai bahan baku industri. Pati yang terkandung di dalam umbi merupakan salah satu aspek penting dalam penentuan klon unggul.

Kandungan pati yang terkandung pada ubi kayu berhubungan dengan kandungan asam siandia (HCN).Menurut Depkes RI (1999) dalam Siboro (2016), ubi kayu memiliki sifat beracun berdasarkan kandungan HCN pada ubi. Ubi kayu manis memiliki kandungan $\mathrm{HCN}<0,05 \mathrm{mg} / \mathrm{g}$. Ubi kayu agak beracun memiliki kandungan HCN 0,05 - 0,08 mg/g. Ubi kayu beracun memiliki kandungan asam sianida $>0,08$ $\mathrm{mg} / \mathrm{g}$. Berdasarkan hasil penelitian, klon yang memiliki kandungan $\mathrm{HCN}$ tertinggi yaitu klon Korem Gatam dengan 0,5130 mg/g dan klon UJ 5 yaitu 0,2153 mg/g. Hal ini menunjukkan bawa klon Korem Gatam dan UJ 5 termasuk ke dalam ubi kayu beracun karena memiliki kandungan HCN yang tinggi. WHO (2004) melaporkan bahwa ubi kayu yang difermentasi selama 96 jam dapat mengurangi $50 \% \mathrm{HCN}$, perendaman 24 jam mengurangi $40 \% \mathrm{HCN}$, dan pengeringan menggunakan sinar matahari mengurangi $15 \% \mathrm{HCN}$.

\section{SIMPULAN}

Klon CMM 96-1-102, 19-Daniel, BL-1, Bayam Liwa 5, dan SL-36 memiliki jumlah ubi lebih banyak dari klon UJ5. Klon CMM 96-1-102, UJ 6, Litbang UK 2, SL36, Korem Gatam, dan UJ6 memiliki bobot ubi segar per tanaman yang lebih tinggi dibandingkan klon UJ5. Klon Litbang UK 2, SL-106, UJ3, UJ6, dan CMM 96-1-102 memiliki indeks panen yang lebih tinggi dibandingkan klon UJ5. Kadar pati tinggi yaitu klon CMM 25-27-23-10-25, CMM 96-1-102, Bayam Liwa 5, BL-1, dan SL-36. Klon pembanding UJ 5 memiliki jumlah ubi terbanyak diikuti dengan klon Nibung. Klon MU 55, Gajah, Nibung, UJ 3, dan Korem Gatam memiliki bobot ubi segar per tanaman yang lebih tinggi dari klon pembanding UJ 5 . Klon pembanding UJ 5 memiliki kadar pati tertinggi dan diikuti oleh klon Nibung dan Korem Gatam. 


\section{DAFTAR PUSTAKA}

Badan Pusat Statistik. 2018. Produksi Ubi Kayu Menurut Provinsi (ton), 19932015.https://www/bps.go.id/link TableDinamis/view/id/880. Diakses 10 Oktober 2018.

Balai Penelitian dan Pengembangan Pertanian. 2011. Agro Inovasi : Inovasi Pengolahan Singkong Meningkatkan Pendapatan dan Diversifikasi Pangan. http://www.litbang.pertanian.go.id/download/one/104/file/Manfaat-Singkong.pdf. Diakses 25 September 2018.

CIAT. 2005. 1. Description of Cassava as a Crop. Report for the 2005 CCER Project IP3 Output 1-2 : Improving Cassava for the Developing World. http://www.ciat.cgiar.org/. Diakses 5 Oktober 2018.

Depkes RI. 1999. Badan Pengawas Perdagangan Berjangka Komoditi, Peristilahan Dalam Perdagangan Berjangka Komoditi. Jakarta. Dalam Siboro, R. 2016. Reduksi kadar sianida tepung ubi kayu (Manihot esculenta Crantz) melalui perendaman ubi kayu dengan NaCO3. Skripsi. hlm 27-28.

Gomes, R.S., C.F. de Almeida, R.M. Junior, dan F.T. Delazari. 2016. Genetic diversity in sweet cassava from the Brazilian middle north religion and selection of genotypes based on morpho-agronomical descriptors. Jurnal Agricultural Research 11(38): 3710-3719.

Karama, S. 2003. Potensi, tantangan dan kendala ubi kayu dalam mendukung ketahanan pangan, p.1-14. Dalam Koes Hartojo et al. (Eds.). Pemberdayaan ubi kayu mendukung ketahanan pangan nasional dan pengembangan agribisnis kerakyatan. Balai Penelitian Tanaman Kacang-kacangan dan Umbiumbian. Badan Penelitian dan Pengembangan Pertanian.

Ntawuruhunga, P. and Dixon, A. 2010. Quantitative variation and interrelationship between factors influencing cassava yield. Journal of Applied Biosciences 26: 1594-1602.

Radjit, B. S., Y. Widodo., N. Saleh., dan N. Prasetiaswati. 2014. Teknologi untuk Meningkatkan Produktivitas dan Keuntungan Usahatani Ubikayu di Lahan Kering Ultisol. Balai Penelitian Tanaman Aneka Kacang dan Ubi. hlm. 54.

Rukmana, R. 1997. Ubi Kayu: Budidaya, Panen, dan Pasca Panen. Kanisius. 85 hlm.

Saleh, N. dan Y. Widodo. 2007. Profil dan peluang pengembangan ubi kayu di indonesia. Buletin Palawija 14: 69-78.

Soenarso dan Soehardi. 2004. Memelihara Kesehatan Jasmani Melalui Makanan. ITB.

Sudarmadji, S., B. Haryono dan Suhardi. 1984. Prosedur Analisa untuk Bahan Makanan dan Pertanian Edisi Ketiga. Liberty. $138 \mathrm{hlm}$.

Sumartono. 2013. Pengaruh Suhu Media Tanam Terhadap Pertumbuhan Vegetative Kentang Hidroponik di Dataran Medium Tropika Basah. Universitas Jendral Sudirman.

Susilawati, S. Nurdjannah, dan S. Putri .2008. Karakteristik Sifat Fisik dan Kimia Ubi Kayu (Manihot esculenta) Berdasarkan Lokasi Penanaman dan Umur Panen Berbeda. Jurnal Teknologi Industri dan Hasil Pertanian 13(2): 63.

Tumewu, P., C. P. Paruntu., dan T. D. Sondakh. 2015. Hasil Ubi Kayu (Manihot esculenta Crantz.) Terhadap Perbedaan Jenis Pupuk. Jurnal LPPM Bidang Sains dan Teknologi 2(2):7-8.

World Health Organization (WHO). 2004. Hydrogen Cyanide and Cyanides: Human Health Aspects. Concise International Chemical Assessment Document 61. 69 $\mathrm{hlm}$ 